Review

\title{
Formation and Aggregation of Gold (Electrum) Nanoparticles in Epithermal Ores
}

\author{
James A. Saunders ${ }^{1, *}$ and Michelle Burke ${ }^{2}$ \\ 1 Department of Geosciences, Auburn University, Auburn, AL 36849, USA \\ 2 Department of Geology and Environmental Earth Science, Miami University, Oxford, OH 45056, USA; \\ burkeml2@miamioh.edu \\ * Correspondence: saundja@auburn.edu; Tel.: +1-334-844-4884
}

Received: 10 August 2017; Accepted: 6 September 2017; Published: 8 September 2017

\begin{abstract}
Here, we review the concept that nanoparticles and colloids may have played a significant role in forming some types of hydrothermal ores deposits, particularly epithermal. This concept was first proposed almost a century ago but the development of new analytical technologies, lab experiments, and the discovery of new epithermal deposits where nanoparticles are evident have added credence to the "gold colloid theory". Nanoparticles are defined to have at least one dimension $<10^{-7} \mathrm{~m}$, and may have different chemical and physical properties than the bulk solids. Colloids are typically $<10^{-6} \mathrm{~m}$ in diameter and have the added characteristic that they are dispersed in another medium. In epithermal ore-forming solutions, gold or electrum nanoparticles nucleate from supersaturated hydrothermal solutions, and thus this is a "far-from-equilibrium" process. In some cases, gold nanoparticles may simply play a transitory role of aggregating to form much coarser-grained crystals, where all of the evidence of nanoparticles precursor phases is not preserved. However, in some epithermal ores, silica nanoparticles also formed, and their co-deposition with gold (electrum) nanoparticles preserved the gold aggregation features as self-organized "fractal" dendrites. Here, we review existing the data on gold and electrum nanoparticles in epithermal ores, present images of electrum nanoparticles and their aggregates, and discuss the significance of gold nanoparticles formation and aggregation in helping to produce some of the highest-grade gold ores in the world.
\end{abstract}

Keywords: gold nanoparticles; colloids; epithermal ores; aggregation

\section{Introduction}

The term nanoparticle (NP) is generally defined in the physics and engineering literature as any solid particle having one or more dimension in the range of 1 to $100 \mathrm{~nm}\left(10^{-9}\right.$ to $\left.10^{-7} \mathrm{~m}\right)$. Colloidal particles can be of a similar size (typically 1-1000 $\mathrm{nm}$ in the chemistry usage) but they have the added requirement that they must be dispersed in a stable manner in another medium composed of different materials, such as an aqueous solution. Thus, perhaps it is more fitting to retain the term colloids for hydrothermal solutions that transport these small particles, but the recent economic geology and geochemistry literature uses both terms [1,2]. Given their size, colloids, and nanoparticles have very-high surface area to volume ratios, which can impart unique chemical properties that can differ from that of the bulk materials [1]. These properties for gold nanoparticles specifically are what are exploited in the fields of nanotechnology in engineering, medicine, biology, and other fields [3-6].

In the first half of the 20th century, researchers contemplated the significance of colloids in the genesis of hydrothermal ore-forming systems, particularly for epithermal gold deposits [7-9]. A few decades later, Barton et al. [10] recognized that fluid inclusions could trap physically transported solid phases (as opposed to daughter mineral phases that precipitated from the inclusion fluids) in hydrothermal ore-forming solutions at Creede, Colorado, and they attempted to calculate the 
ore-solution velocity by using the particle size of the trapped solid particles. Boyle [11] summarized the previous work on the "gold colloid theory" and proposed that more research was warranted on the topic. The discovery of the bonanza epithermal Sleeper Au-Ag deposit in the mid-1980s in Nevada, and the discovery of nanoparticulate textures [12-14], gave new impetus to the concept that gold-colloid transport can be important, at least in epithermal ore systems. Further, Herrington and Wilkinson [15] proposed that gold and silica colloids could be important in the higher temperature, deeper, "mesothermal" gold systems based on textural interpretations. A number of review papers have been published recently [1,16-19] on the occurrence of gold nanoparticles in nature, and they contain many additional references both from within and outside of the ore-deposits realm. Hough et al. [1] emphasized that both native copper and silver form metallic nanoparticles similar to those that are composed of gold or electrum. Although we describe the role of nanoparticles in epithermal ore formation here, perhaps such particles are important in other systems. For example, gold colloids, nanoparticles, and/or nanocrystals also have been documented in "supergene" \pm bacterial processes related to weathering of gold ores and gold-nugget formation [19-21], in volcanic fumaroles [22,23], in Carlin-type gold deposits [24,25], and also in active geothermal systems [2,26-28]. Finally, metallic sulfide nanoparticles are significant components in the "black smoke" discharging from submarine hydrothermal vents [29-31].

Returning to epithermal ores, Saunders [13] showed a scanning electron microscope (SEM) image of electrum dendrites that appeared to have formed from the aggregation of smaller colloid-sized particles. Electrum nanoparticles are an example of "mineral nanoparticles" that can be present both as true nanoparticles, and also as larger minerals. Thus, they appear to occur as short-lived intermediaries between metal ions in true solution and minerals [32]. Metallic nanoparticles appear to form from supersaturated solutions and can form dendrites by the self-assembly and aggregation of the nanoparticles (Figure 1) [33]. These dendrites are typically an intermediary stage to more traditional crystal formation as the infilling of branches of the dendrites occurs. In epithermal ores, the dendrites of electrum appear to be preserved due to the infilling of other nanoparticles between the branches, such as silica nanoparticles [12,14,34]. The "fractal" electrum dendrites (discussed below) have been observed in many Tertiary bonanza epithermal ores in northern Nevada, and have been interpreted to be evidence of nanoparticle nucleation and aggregation in ore formation [35,36]. More recently, similar textures and genetic interpretations have been made from ores from the southeastern USA [37] and Bulgaria [38]. Finally, disseminated electrum nanoparticles have recently been discovered in the epithermal Round Mountain (Nevada) deposit and have been proposed to be precursors for coarser electrum crystals there $[39,40]$.

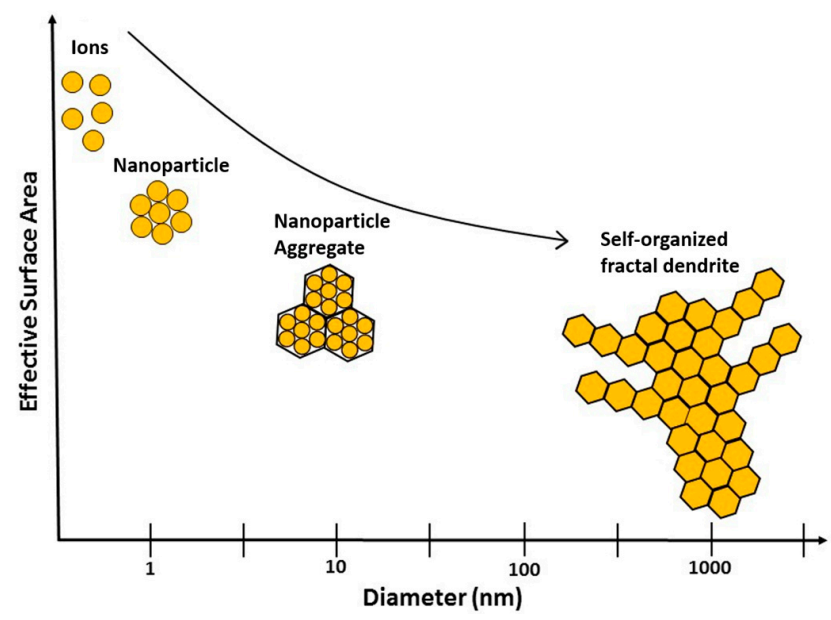

Figure 1. Diagrammatic illustration of the progression from dissolved gold ions, to nanoparticles, to self-organized fractal dendrites in epithermal hydrothermal systems. In general, effective surface area of nanoparticles increases with decreasing size. 


\section{Results}

\subsection{Bonanza Epithermal Ore Characteristics}

The term "bonanza" implies a relatively rich ore of gold \pm silver, and it has been proposed that metal nanoparticle formation and aggregation are important processes in producing such high-grade epithermal ores [12-14]. Epithermal deposits, which typically form at temperatures of $<350{ }^{\circ} \mathrm{C}$ in the upper $1 \mathrm{~km}$ of the crust, and often exhibit open-space-filling textures, are generally subdivided based on their mineralogy and physicochemical conditions of formation [41,42]. These subdivisions include: (1) the most common type, low sulfidation (LS) or "adularia-sericite" ores that often formed from low-salinity, near-neutral $\mathrm{pH}$ solutions (low magmatic:meteoric water ratio), and typically have a relatively low base metal content. The LS ores have electrum \pm gold as principal ore minerals, along with associated silver sulfides, selenides, tellurides, and sulfosalts, which generally occur with such gangue minerals as quartz, opal, adularia, and calcite (examples: Sleeper, Round Mountain, Midas, Nevada); (2) High sulfidation or "acid-sulfate" ores that form from acidic solutions (high magmatic: meteoric ratio) with electrum or gold as the main ore mineral, typically associated with the copper-arsenic minerals enargite or luzonite, and quartz, alunite, jarosite, and dickite are the common associated gangue minerals (Examples: Goldfield, Nevada, Summitville, Colorado); and (3) Intermediate sulfidation ores, which are generally transitional between the end members 1 and 2 above, but also have a higher salinity ore-forming solutions, which leads to higher Ag:Au ratios in the ores, higher content of associated base metal-sulfide minerals (examples: Mexican silver deposits; Comstock, Nevada; Creede, Colorado). We, and others [38], have focused on LS ores for our research on metallic nanoparticles, and thus we cannot affirm that they are universally significant in other epithermal ore types, but our cursory observations suggest that they might be. The western United States of America (USA) in general, and Nevada in particular, hosts numerous epithermal ores with representative examples from each of the three of the subdivisions. In Nevada, they are generally Tertiary in age but are associated with varying tectonic and magmatic environments [43]. Our research on LS ores in Nevada has focused on the giant Oligocene ( $25 \mathrm{Ma})$ Round Mountain deposit in central Nevada and several middle Miocene ( 16-14 Ma) deposits in northern Nevada. Details of the geology and ore characteristics of the Round Mountain deposit have been documented previously $[39,40,43,44]$, as have the middle Miocene ores of northern Nevada [13,14,35,36,43,45-47], the latter of which are associated with the volcanism attending the initial emergence of the Yellowstone mantle plume [35,45]. In the Nevada LS ores, electrum is the principal (and most valuable) ore mineral, with associated byproduct silver minerals, particularly in the middle Miocene ores. In the middle Miocene LS ores, in addition to electrum, silver typically occurs in acanthite $\left(\mathrm{Ag}_{2} \mathrm{~S}\right)$, naumannite $\left(\mathrm{Ag}_{2} \mathrm{Se}\right)$, and aguilarite $\left(\mathrm{Ag}_{4} \mathrm{SeS}\right)$, and thus the middle Miocene ores are generally Se-rich. Other examples of Se-rich LS epithermal ores include Silver City, Idaho; Republic, Washington; and Hishikari, Kushikino; and, Koryu deposits of Japan [45]. In the highest-grade middle Miocene ores, dendritic textures of Au-Ag minerals are common and apparently formed by the aggregation of nanoparticles of electrum, Ag-Se-S phases, and less commonly chalcopyrite [37]. Lead-, osmium-, copper-, and sulfur-isotope studies have been conducted specifically on bonanza ore minerals in the middle Miocene ores, and the results indicate a mafic-magmatic source for the ore minerals $[45,48,49]$. Thus, those results suggest that the: (1) bonanza deposits derived the bulk of ore metals from a magmatic-fluid contribution to the shallow geothermal system; and (2) bulk of the metallic nanoparticles probably formed close to their source magma chambers and were transported upward to the epithermal environment where they were deposited by aggregation of the nanoparticles [49].

\subsection{Aggregation of Metallic Nanoparticles}

The most characteristic feature of metallic nanoparticle aggregation in epithermal ores is the preserved, self-organized "fractal" dendrites of gold and silver minerals, which were first documented at the Sleeper deposit, Nevada [12-14]. These dendrites, which are now crystalline based on X-ray 
diffraction, typically retain evidence of their nanoparticle precursors on their surfaces [13]. Their fractal nature is caused by far-from-equilibrium processes that are caused by extreme supersaturation of the ore-forming solutions. These conditions have been interpreted to have been caused by some combination of solution boiling, mixing, and temperature drop [14]. Natural fractals are self-similar over several scales, and the three-dimensional metallic dendrites typical of the epithermal ores formed by sticking of nanoparticles that had random, chaotic trajectories [14,34]. Laboratory investigations have shown that gold [50,51] and silver [33] nanoparticles aggregate by a similar process of self-assembly to make fractal dendrites. In particular, the nanoparticles' aggregation is governed by a kinetically driven process called diffusion-limited aggregation (DLA) [33,51,52], which results in characteristic tree-like dendrites with similar fractal dimensions. Saunders and Schoenly [14,34] showed that dendrites in epithermal ores had similar fractal dimensions to those produced in the lab by gold nanoparticle aggregation, and they proposed that a modified DLA produced the natural fractal dendrites from the Sleeper deposit. The gold nanoparticles appear to efficiently stick upon collisions by rapidly forming metallic bonds [51], and that is also controlled by the crystal symmetry of the metallic nanoparticles; for example, the mutual collision of the particles along $\{111\}$ crystallographic orientation appears to enhance the particle sticking [33]. However, the resulting fractal dendrites' overall geometry is not a function of the underlying crystal structure [14,34,35].

As discussed above, in a simple laboratory experiment utilizing one type of metallic nanoparticles, the fractal dendrites are transitory precursors to the formation of metal crystals as metal nanoparticles, and perhaps atoms infill the spaces between dendrite branches, resulting in the eventual destruction of textural evidence of the aggregation process. However, in the epithermal ores, silica (opal) nanoparticles commonly infill the metal branches of the fractal dendrites, and thus aid in the preservation of evidence of the self-assembly process [34,35]. The term dendrite can have multiple meanings in the science literature. For example, manganese oxyhydroxide minerals can form 2-dimensional fractal dendrites along planar surfaces, or native gold and silver can make 3-dimensional planar dendritic crystals exhibiting a reticulate shape that is controlled by their crystal structures [36]. Those crystal forms differ from the 3-diemnsional fractal dendrites formed by self-assembly, which is demonstrated in Figure 2 in a sample of silver-rich ore from Creede, Colorado. In that sample, coarse-grained $(1-5 \mathrm{~cm})$ reticulate "blades" of native silver formed initially, and then they were subsequently encrusted by self-organized fractal dendrites of native silver. Also, note the matrix for both types of dendrites is opaline silica (formed by silica-colloid deposition), which as discussed above, aids in the preservation of evidence of the nanoparticle aggregation process. The formation of opal as opposed to quartz or chalcedony is additional evidence of the far-from-equilibrium chemical conditions during bonanza ore formation [12]. Fractal dendrites formed by nanoparticle aggregation in bonanza epithermal ores were first recognized for electrum [12], then Ag-Se-S phases [35,36], and more recently chalcopyrite $[37,49]$. Finally, other textural features of bonanza ores have added further insights about the potential physical transport and also deposition of metallic nanoparticles [36].

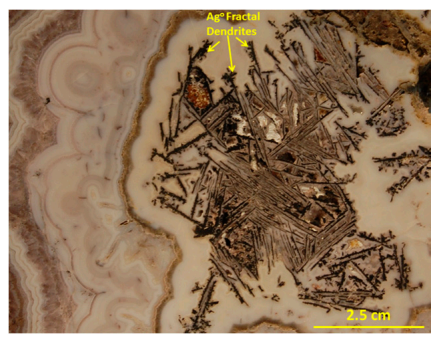

Figure 2. Photograph of native silver (black) in opal from the Amethyst vein, Last Chance mine, Creede, Colorado. We interpret the reticulate dendritic texture to represent silver precipitation from Ag-super-saturated solutions, which are then encrusted by self-organized fractal dendrites formed by the aggregation of Ag-colloids. Used with permission from the Colorado School of Mines Geology Museum. 
The aforementioned ore textures are strikingly visible at both the hand-sample scale and also under the petrographic microscope. We recently have applied electron microscopy to characterize the size and morphology of gold/electrum nanoparticles in these ores [39]. At the Round Mountain deposit, Nevada, electrum nanoparticles occur as spheroidal shapes $\sim 2-10 \mathrm{~nm}$ in diameter (Figure 3).

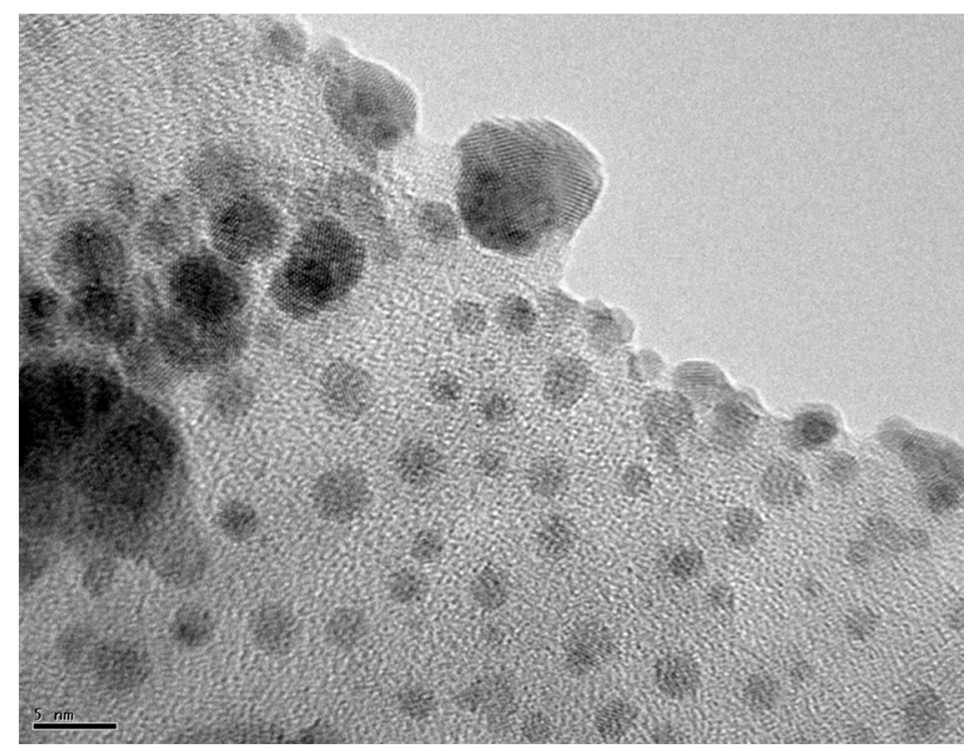

Figure 3. TEM image of spheroidal gold or electrum nanoparticles imbedded in sericite from the Round Mountain deposit Nevada, which have been proposed as the precursors for the eventual coarser-grained crystals typical of the deposit [39].

TEM images of Au or electrum nanoparticles from Round Mountain are similar in their general appearance to TEM images of commercially produced gold nanoparticles of a similar size [52]. The aggregation of both electrum and silica colloids were interpreted to result in the formation of the extremely high-grade ores of the Sleeper deposit, Nevada [12-14]. The spectacular ores from Sleeper are characterized by multiple layers of electrum (Figure 4A) and silica (originally opal) that formed by progressive deposition along the vein wall over time, leading to perhaps $100 \mathrm{~s}$ of gold-depositing events in the veins [13]. The electrum-rich layers are characterized by "forests" of coalescing fractal dendrites, shown in Figure 4B,C in two mutually perpendicular orientations to better characterize their 3-dimensional morphology. On a smaller scale, SEM images show that the dendrites are composed of aggregates of electrum nanoparticles (Figure $4 \mathrm{D}, \mathrm{E}$ ). The epithermal electrum nanoparticles and their aggregates (fractal dendrites) are not always imbedded in fine-grained silica. For example, dendrites at the epithermal Jumbo deposit ( 1.5 km ESE of Sleeper) are hosted exclusively by adularia (Figure 5), which perhaps played a role in causing coarser-grained dendrites to form. The origin of such adularia-only (no silica) veins with electrum is enigmatic, but probably they required the leaching of an aluminum-rich country rock such as meta-pelites at Jumbo [45]. Although the coarse-grained dendrites are imbedded in adularia at Jumbo, there are disseminated electrum nanoparticles and small aggregates in the ores as well (Figure 5). Dissolution of the adularia with hydrofluoric acidreleased and concentrated dispersed nanoparticles or nanocrystals of electrum, which allowed for the ease of imaging with the SEM (Figure 6). We are currently investigating and imaging electrum nanoparticles from additional middle Miocene epithermal ores in northern Nevada, and preliminary results show electrum nanoparticles are apparently universally present in these ores. 

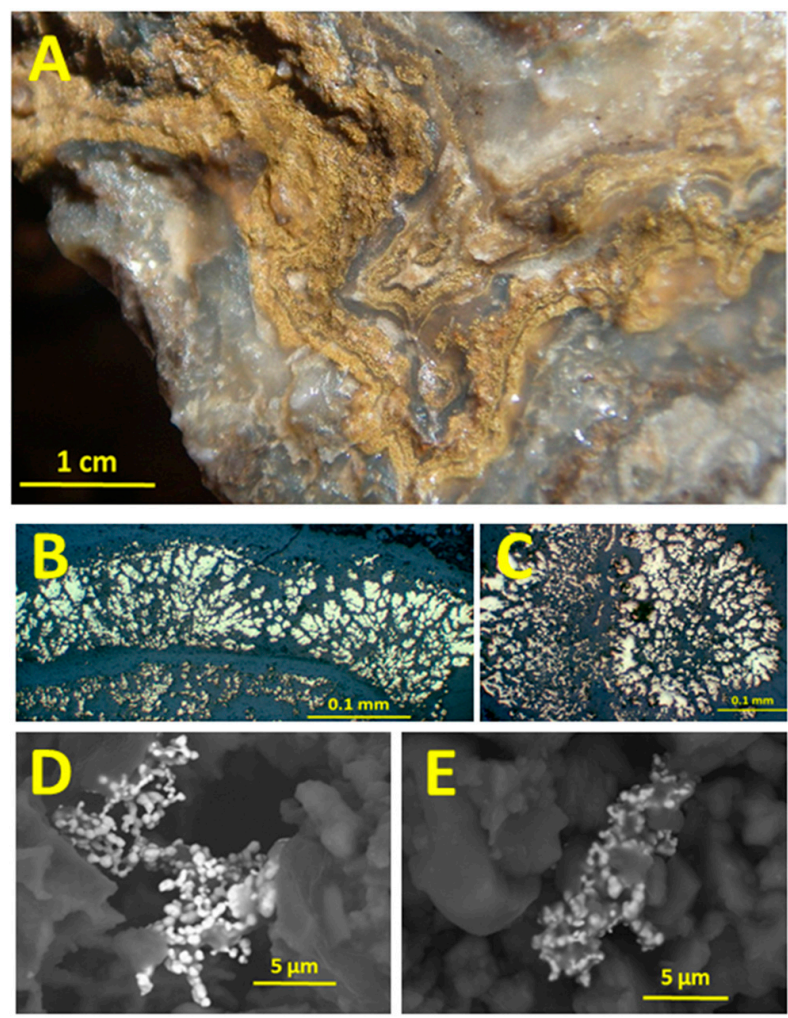

Figure 4. Three different scales of characteristic electrum textures from the Sleeper deposit, Humboldt County, Nevada. (A) Photograph of electrum-rich colloform bands in opaline silica. The electrum-rich bands formed sequentially as coatings of the vein walls by aggregation of gold nanoparticles/colloids. All that glitters in the image is gold (B) Photomicrograph (reflected light) of fractal dendrites of electrum within a single band, oriented perpendicular to the vein wall at the time of gold deposition. (C) Photomicrograph (reflected light) of fractal dendrites of electrum oriented parallel to the vein wall. (D,E) SEM images of self-organized fractal dendrites composed of aggregates of electrum nanoparticles, which were exposed for imaging by dissolution of the surrounding silicate gangue minerals with HF.

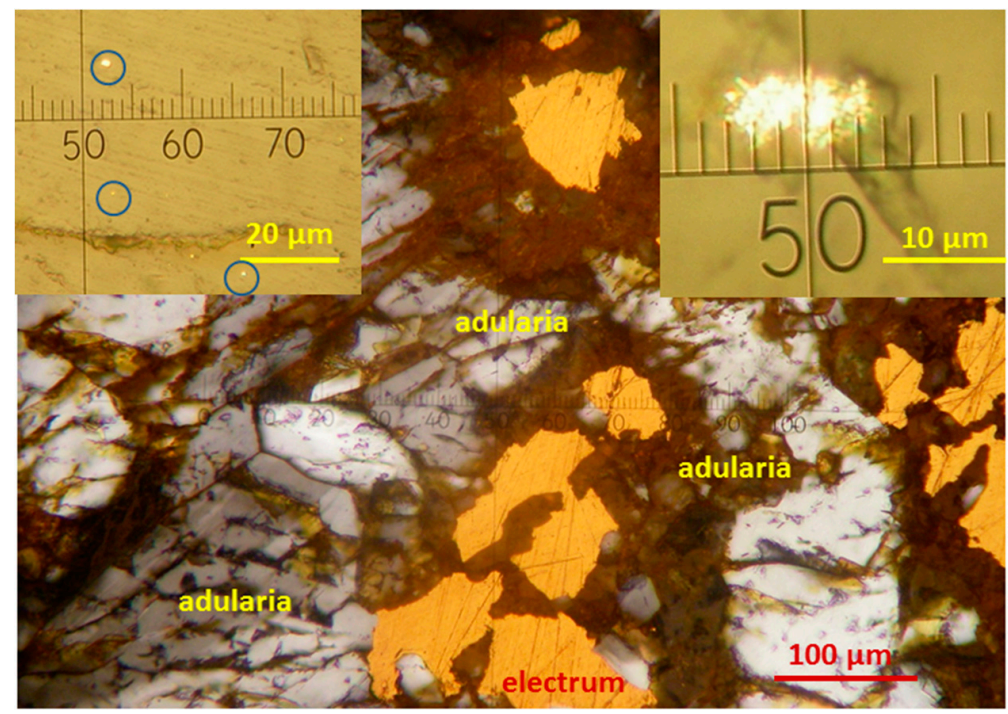

Figure 5. Photomicrographs of adularia-electrum veinlet from the Jumbo deposit, Humboldt County, Nevada, with upper left inset showing adularia with inclusions of electrum particles (circled) $\leq 2 \mu \mathrm{m}$ in diameter, and upper right inset showing an aggregate of nanoparticles. 


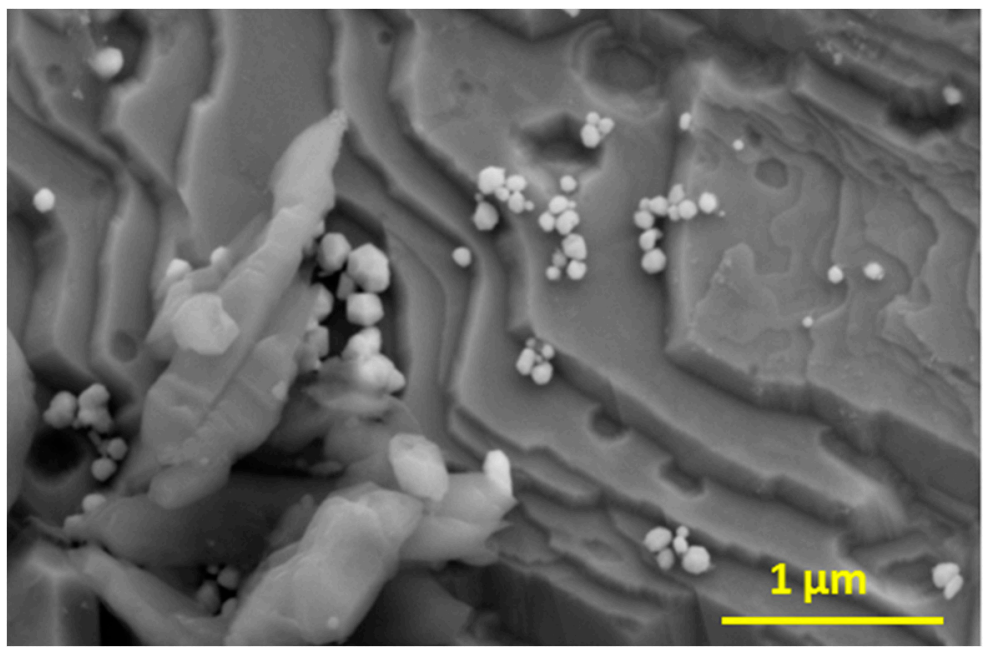

Figure 6. SEM image of electrum nanoparticles and nanocrystals from Jumbo (released by dissolution of the adularia with $\mathrm{HF}$ ).

\section{Discussion}

It is clear that nanoparticle formation and aggregation were significant processes in the formation of Tertiary epithermal ores in Nevada, Eastern Europe, and apparently, even at least one (Cambrian) epithermal deposit of the Carolina Slate Belt of the SE USA [37]. Although, the presence of electrum nanoparticles in the ores does not imply that gold cannot also be precipitated directly from solution as well. In LS, epithermal ore-forming fluids, gold is generally transported in solution as a gold bisulfide complex such as $\mathrm{Au}(\mathrm{HS})_{2}{ }^{-}$and the destabilization of that complex, caused by solution boiling, cooling, or mixing can lead to the destabilization of the complex, resulting in a gold-supersaturated solution [53]. Such a gold-supersaturated solution could potentially re-equilibrate by: (1) precipitating and nucleating gold nanoparticles; (2) precipitating gold on existing nanoparticles; or (3) precipitating crystalline gold along the vein walls. Perhaps all three of these processes are important in forming the highest-grade epithermal ores.

If one accepts the proposal that gold nanoparticles are significant contributors to epithermal ore formation, then that begs the question: where and when did they form? Early ideas centered on their in-situ formation close to where they formed, as a consequence of boiling of the ore-forming solutions [12-14]. That working hypothesis was cast into doubt by isotopic studies conducted on the epithermal ores containing fractal electrum dendrites. Initially, lead isotope ratios were measured on the trace amounts of lead in the electrum [48], and the results were surprising. The lead isotopic ratios of the electrum were similar to the middle Miocene basalts (e.g., Columbia River basalts), which Kamenov et al. [48] interpreted to mean that the nanoparticles had nucleated close to their mafic magma-chamber source and not in the shallow epithermal setting. Further, samples from the Jumbo deposit, like that shown in Figure 5, were used to analyze the lead isotopes in both the electrum and the associated adularia. It was erroneously assumed they should be in isotopic equilibrium, and thus if that was proven to be correct, we could use the more abundant and more lead-rich adularia as a proxy for lead-isotopic composition of associated electrum. However, adularia contained lead that must have been derived from the surrounding country rocks. These data were incorporated into an overall model for the origin of middle Miocene bonanza epithermal ore formation in northern Nevada [45]. More recent Os-, $\mathrm{Cu}$-, and S-isotope studies on these ores supported previous interpretations based initially on lead isotopes [49]. The implications of the isotope data are that perhaps gold nanoparticles formed at depth near their source (mafic) magma chambers and were physically transported to the shallow epithermal environment [49]. 
For the nanoparticles to be preserved, the transporting solutions would have had to remain saturated with respect to gold/electrum, and thus the particles probably grew bigger during transport. We envision that this "transporting solution" was a low-density magmatic fluid like those that have been described as separating from more saline, higher density fluids in the "porphyry environment" [54,55]. These nanoparticle-bearing, low-density magmatic fluids would have been enriched in such volatile elements as $\mathrm{Au}, \mathrm{Ag}, \mathrm{Cu}, \mathrm{Se}, \mathrm{As}$, etc. [56], and they eventually encountered and mixed with shallow, meteoric-water-dominated geothermal systems in the epithermal environment [45,49]. Eventually pressure decreased enough to trigger the boiling of the epithermal solutions (the mixture of the low-density magmatic "vapors" and the heated meteoric waters) and more gold and silver perhaps precipitated, but boiling also provides the physical conditions necessary to cause gold nanoparticle aggregation and the formation of fractal dendrites. For example, boiling would cause chaotic randomness of particle trajectories, which is required to form self-assembled aggregates by DLA. Further, boiling would also lead to increased particle velocities, which can lead to overcoming surface-charge repulsions, causing effective particle sticking by a process called orthokinetic aggregation [34]. Recently, Hannington et al. [2] proposed that deeper reservoirs of solutions containing gold nanoparticles can contribute them episodically to shallow geothermal systems, and thus might be a plausible explanation for the formation of bonanza epithermal ores.

\section{Conclusions}

Gold/electrum nanoparticles are common in the LS epithermal ores we have studied in Nevada, USA, and there is no reason to believe the Nevada deposits are unique when compared to others elsewhere in the world. Their importance in helping to form the highest-grade epithermal ores seems to be a warranted conclusion as of now, but more research is required on this. At the very least, the formation and aggregation of gold nanoparticles appear to be a transitory step in gold crystallization from gold-supersaturated solutions. In epithermal solutions supersaturated with respect to gold and amorphous silica, the gold-nanoparticle aggregates can be preserved as self-organized fractal dendrites embedded in opal. Disseminated gold or electrum nanoparticles also occur in opal, quartz, and adularia in the epithermal ores we have studied.

There are two likely causes of gold (electrum) nanoparticle formation in epithermal solutions: (1) Boiling, which is known to cause gold supersaturated solutions in epithermal and geothermal systems, could cause the formation of gold nanoparticles near the site of their aggregation and deposition [14], although ore textures indicate that there could be a significant amount of physical transport of the nanoparticles in the epithermal setting [36]; or (2) Gold nanoparticles form much deeper and are transported upward to their ultimate site of deposition in the bonanza ore shoots, and boiling is important in causing the nanoparticles to collide and aggregate. Isotopic investigations lend support to the latter hypothesis [45,48,49], but more research is warranted.

The recent discovery of gold nanoparticles in sub-aerial geothermal systems $[2,26,27]$ and submarine hydrothermal vents [28], along with the documentation of metal-sulfide nanoparticles in the "black smoke" emanating from submarine vents, suggest that gold and other metallic nanoparticles may be important contributors to a variety of hydrothermal ores, such as volcanogenic massive sulfideor Carlin-type ores. However, the essential requirement appears to be the evolution of hydrothermal fluids to form gold-supersaturated, far-from-equilibrium conditions that are capable of forming nanoparticles. In epithermal ores, evidence of nanoparticle formation is recorded by electrum nanoparticle inclusions trapped in gangue minerals and the characteristic fractal dendrites formed from nanoparticle aggregation.

Acknowledgments: Funding for this research was provided by three grants to James A. Saundersby the USA. National Science Foundation (latest: EAR-1247857) and also the AMAX (American Metal Climax, Inc.) Foundation, as well as a Geological Society of America Graduate Student Research Grant to MB. We thank Bruce Geller of the Colorado School of Mines Geology Museum for the photograph in Figure 2. 
Author Contributions: Both authors collected and reviewed the appropriate literature, collaborated in preparation of figures and conducting ore image analyses and both wrote portions of the manuscript.

Conflicts of Interest: The authors declare no conflict of interest. The founding sponsors had no role in the design of the study; in the collection, analyses, or interpretation of data; in the writing of the manuscript, and in the decision to publish the results.

\section{References}

1. Hough, R.; Reich, M.; Noble, R. Noble metal nanoparticles in ore systems. In Nature's Nanostructures; Barnard, A.S., Guo, H., Eds.; Pan Stanford Publishing Pte. Ltd. (CRC Press): Boca Raton, FL, USA, 2012; pp. 141-167, ISBN 978-981-4316-82-8.

2. Hannington, M.; Harðardóttir, V.; Garbe-Schönberg, D.; Brown, K.L. Gold enrichment in active geothermal systems by accumulating colloidal suspensions. Nat. Geosci. 2016, 9, 299-303. [CrossRef]

3. Grzelczak, M.; Perez-Juste, J.; Mulvaney, P.; Liz-Marzan, L.M. Shape control in gold nanoparticle synthesis. Chem. Soc. Rev. 2008, 37, 1783-1791. [CrossRef] [PubMed]

4. Giljohann, D.C.; Seferos, D.S.; Daniel, W.L.; Massich, M.D.; Patel, P.C.; Mirkin, C.A. Gold nanoparticles for biology and medicine. Angew. Chem. Int. Ed. Engl. 2010, 49, 3280-3294. [CrossRef] [PubMed]

5. Personick, M.L.; Mirkin, C.A. Making sense of the mayhem behind shape control in the synthesis of gold nanoparticles. J. Am. Chem. Soc. 2013, 135, 18238-18247. [CrossRef] [PubMed]

6. Chen, Y.; Fernandes, A.A.; Erbe, A. Control of shape and surface crystallography of gold nanocrystals for electrochemical applications. Electrochim. Acta 2013, 113, 810-816. [CrossRef]

7. Boydell, H.C. The role of colloidal solutions in the formation of mineral deposits. Inst. Min. Metall. Trans. 1924, 34, 145-337.

8. $\quad$ Lindgren, W. Mineral Deposits, 4th ed.; McGraw Hill: New York, NY, USA, 1933; p. 237.

9. Frondel, C. Stability of colloidal gold under hydrothermal conditions. Econ. Geol. 1938, 33, 1-20. [CrossRef]

10. Barton, P.B., Jr.; Bethke, P.M.; Toulmin, P., III. An attempt to determine the vertical component of flow rate of ore-forming solutions in the $\mathrm{OH}$ vein, Creede, Colorado. In Proceedings of the IAGOD 1970 Meeting, Kyoto, Japan, 28 August-2 September 1971; pp. 132-136.

11. Boyle, R.W. The Geochemistry of Gold and Its Deposits; Geological Survey of Canada: Ottawa, ON, Canada, 1979; Volume 280, p. 584.

12. Saunders, J.A. Colloidal transport of gold and silica in epithermal precious metal systems: Evidence from the Sleeper deposit, Humboldt County, Nevada. Geology 1990, 18, 757-760. [CrossRef]

13. Saunders, J.A. Silica and gold textures at the Sleeper deposit, Humboldt County, Nevada: Evidence for colloids and implications for ore-forming processes. Econ. Geol. 1994, 89, 628-638. [CrossRef]

14. Saunders, J.A.; Schoenly, P.A. Boiling, colloid nucleation and aggregation, and the genesis of bonanza gold mineralization at the Sleeper Deposit, Nevada. Miner. Depos. 1995, 30, 199-211. [CrossRef]

15. Herrington, R.J.; Wilkinson, J.J. Colloidal gold and silica in mesothermal vein systems. Geology 1993, 21, 539-542. [CrossRef]

16. Hough, R.M.; Noble, R.R.P.; Hitchen, G.J.; Hart, R.; Reddy, S.M.; Saunders, M.; Clode, P.; Vaughan, D.; Lowe, J.; Anand, R.R.; et al. Naturally occurring gold nanoparticles and nanoplates. Geology 2008, 36, 571-574. [CrossRef]

17. Hough, R.M.; Butt, C.R.M.; Buhner, J.F. The mineralogy, crystallography and metallography of gold. Elements 2009, 5, 297-302. [CrossRef]

18. Hough, R.M.; Noble, R.R.P. Colloidal gold nanoparticles in ore systems. Geochim. Cosmochim. Acta 2010, $74, \mathrm{~A} 420$.

19. Hough, R.M.; Noble, R.R.P.; Reich, M. Natural gold nanoparticles. Ore Geol. Rev. 2011, 42, 55-61. [CrossRef]

20. Osovetsky, B.M. Aggregation of nanogold particles in the environment. Nat. Resour. Res. 2015, 25, $241-253$. [CrossRef]

21. Shuster, J.; Reith, F.; Cornelis, G.; Parson, J.E.; Parson, J.M.; Southam, G. Secondary gold structures: Relics of past biogeochemical transformations and implications for colloidal gold dispersion in subtropical environments. Chem. Geol. 2017, 450, 154-164. [CrossRef]

22. Taran, Y.A.; Bernard, A.; Gavilanes, J.-C.; Africano, F. Native gold in mineral precipitates from high-temperature volcanic gases of Colima volcano, Mexico. Appl. Geochem. 2000, 15, 337-346. [CrossRef] 
23. Zelenski, M.; Kamenetsky, V.S.; Hedenquist, J. Gold recycling and enrichment beneath volcanoes: A case study of Tolbachik, Kamchatka. Earth Planet. Sci. Lett. 2016, 43, 735-746. [CrossRef]

24. Palenik, C.S.; Utsunomiya, S.; Reich, M.; Kesler, S.E.; Ewing, R.C. “Invisible” gold revealed: Imaging of gold nanoparticles in a Carlin-type deposit. Am. Mineral. 2004, 89, 1359-1366. [CrossRef]

25. Reich, M.; Kesler, S.E.; Utsunomiya, S.; Palenik, C.S.; Chryssoulis, S.L.; Ewing, R.C. Solubility of gold in arsenian pyrite. Geochim. Cosmochim. Acta 2005, 69, 2781-2796. [CrossRef]

26. Pope, J.G.; Brown, K.L.; McConchie, D.M. Gold Concentrations in springs at Waiotapu, New Zealand: Implications for precious metal deposition in geothermal systems. Econ. Geol. 2005, 100, 677-687. [CrossRef]

27. Kanellopoulos, C.; Mitropoulos, P.; Valsami-Jones, E.; Voudouris, P. A new terrestrial active mineralizing hydrothermal system associated with ore-bearing travertines in Greece (northern Euboea Island and Sperchios area). J. Geochem. Explor. 2017, 179, 9-24. [CrossRef]

28. Gartman, A.; Hannington, M.; Jamieson, J.W.; Peterkin, B.; Garbe-Schönberg, D.; Findlay, A.J.; Fuchs, S.; Kwasnitschka, T. Boiling-induced formation of colloidal gold in black smoker hydrothermal fluids. Geology 2017; under review.

29. Yucel, M.; Gartman, A.; Chan, C.; Luther, G.W., III. Hydrothermal vents as a kinetically stable source of iron sulphide-bearing nanoparticles to the ocean. Nat. Geosci. 2011, 4, 367-371. [CrossRef]

30. Gartman, A.; Findlay, A.J.; Luther, G.W., III. Nanoparticulate pyrite and other nanoparticles are a widespread component of hydrothermal vent black smoker emissions. Chem. Geol. 2014, 366, 32-41. [CrossRef]

31. Gartman, A.; Luther, G.W., III. Comparison of pyrite $\left(\mathrm{FeS}_{2}\right)$ synthesis mechanisms to reproduce natural $\mathrm{FeS}_{2}$ nanoparticles found at hydrothermal vents. Geochim. Cosmochim. Acta 2013, 120, 447-458. [CrossRef]

32. Hochella, M.F., Jr.; Lower, S.K.; Maurice, P.A.; Penn, R.L.; Sahai, N.; Sparks, D.L.; Twining, B.S. Nanominerals, mineral nanoparticles, and Earth systems. Science 2008, 319, 1631-1635. [CrossRef] [PubMed]

33. Zhou, Q.; Wang, B.; Wang, P.; Dellago, C.; Wang, Y.; Fang, Y. Nanoparticle-based crystal growth via multistep self-assembly. CrystEngComm 2013, 15, 5114-5118. [CrossRef]

34. Saunders, J.A.; Schoenly, P.A. Fractal structure of electrum dendrites in bonanza epithermal Au-Ag deposits. In Fractal Geometry and Its Use in the Earth Sciences; Barton, C.C., LaPointe, P.R., Eds.; Plenum Publishing: New York, NY, USA, 1995; pp. 251-261.

35. Saunders, J.A.; Schoenly, P.A.; Cook, R.B. Electrum disequilibrium crystallization textures in volcanic-hosted bonanza epithermal gold deposits. In Geology and Ore Deposits of the America Cordillera Symposium Proceeding; Coyner, A.R., Fahey, P.L., Eds.; Geological Society of Nevada: Reno-Sparks, NV, USA, 1996; pp. 173-179.

36. Saunders, J.A.; Vikre, P.; Unger, D.L.; Beasley, L. Colloidal and physical transport textures exhibited by electrum and naumannite in bonanza epithermal veins from western USA, and their significance. In Great Basin Evolution and Metallogeny Symposium Proceedings; Steininger, R., Pennell, W., Eds.; Geological Society of Nevada: Reno-Sparks, NV, USA, 2011; pp. 825-832.

37. Saunders, J.A. Textural evidence of episodic introduction of metallic nanoparticles into bonanza epithermal ores. Minerals 2012, 2, 228-243. [CrossRef]

38. Marinova, I.; Ganev, V.; Titorenkova, R. Colloidal origin of colloform-banded textures in the Paleogene low-sulfidation Khan Krum gold deposit, SE Bulgaria. Miner. Depos. 2014, 49, 49-74. [CrossRef]

39. Burke, M. An Electron Microscopy Investigation of Gold and Associated Minerals from Round Mountain, Nevada. Master's Thesis, Miami University, Oxford, OH, USA, 2017.

40. Burke, M.; Rakovan, J.; Krekeler, M.P.S. A study by electron microscopy of gold and associated minerals from Round Mountain, Nevada. Ore Geol. Rev. 2017, 89. [CrossRef]

41. Sillitoe, R.H.; Hedenquist, J.W. Linkages between volcanotectonic settings, ore-fluid compositions, and epithermal precious metal deposits. In Volcanic, Geothermal, and Ore-Forming Fluids: Rulers and Witnesses of Processes within the Earth; Society of Economic Geologists: Littleton, CO, USA, 2003; pp. 315-343.

42. Saunders, J.A.; Hofstra, A.H.; Goldfarb, R.J.; Reed, M.H. Geochemistry of hydrothermal gold deposits. In Treatise on Geochemistry, 2nd ed.; Holland, H.D., Turekian, K.K., Eds.; Elsevier: Oxford, UK, 2014; Volume 13, pp. 383-424.

43. John, D.A. Miocene and early Pliocene epithermal gold silver deposits in the in the northern Great Basin, western USA: Characteristics, distribution, and relationship to magmatism. Econ. Geol. 2001, 96, 1827-1853.

44. Sander, M.V.; Einaudi, M.T. Epithermal deposition of gold during transition from propylitic to potassic alteration at Round Mountain, Nevada. Econ. Geol. 1990, 85, 285-311. [CrossRef] 
45. Saunders, J.A.; Unger, D.L.; Kamenov, G.D.; Fayek, M.; Hames, W.E.; Utterback, W.C. Genesis of Middle Miocene Yellowstone-hotspot-related bonanza epithermal Au-Ag deposits, Northern Great Basin Region, USA. Miner. Depos. 2008, 43, 715-734. [CrossRef]

46. John, D.J.; Hofstra, A.H.; Fleck, R.F.; Brummer, J.E.; Saderholm, E.C. Geologic setting and genesis of the Mule Canyon low-sulfidation epithermal gold-silver deposit, north-central Nevada. Econ. Geol. 2003, 98, 425-463. [CrossRef]

47. Leavitt, E.D.; Spell, T.L.; Goldstrand, P.M.; Arehart, G.G. Geochronology of the Midas low-sulfidation gold-silver deposit, Elko County Nevada. Econ. Geol. 2004, 99, 1665-1686. [CrossRef]

48. Kamenov, G.D.; Saunders, J.A.; Hames, W.E.; Unger, D. Mafic magmas as sources for gold in middle-Miocene epithermal deposits of northern Great Basin, USA: Evidence from $\mathrm{Pb}$ isotopic compositions of native gold. Econ. Geol. 2007, 102, 1191-1195. [CrossRef]

49. Saunders, J.A.; Mathur, R.; Kamenov, G.D.; Shimizu, T.; Brueseke, M.E. New isotopic evidence bearing on bonanza (Au-Ag) epithermal ore-forming processes. Miner. Depos. 2016, 51, 1-11. [CrossRef]

50. Weitz, D.A.; Huang, J.S. Self-similar structures and the kinetics of aggregation of gold colloids. In Kinetics of Aggregation and Gelation; Family, F., Landau, D.P., Eds.; Elsevier: New York, NY, USA, 1984; pp. 19-27.

51. Weitz, D.A.; Oliveria, M. Fractal structures formed by kinetic aggregation of aqueous gold colloids. Phys. Rev. Lett. 1984, 52, 1433-1436. [CrossRef]

52. Scott, M.C.; Chen, C.-C.; Mecklenburg, M.; Zhu, C.; Xu, R.; Ercius, P.; Dahmen, U. Electron tomography at 2.4-ångström resolution. Nature 2012, 483, 444-447. [CrossRef] [PubMed]

53. Seward, T.H.; Barnes, H.L. Metal transport by hydrothermal ore fluids. In Geochemistry of Hydrothermal Ore Deposits, 3rd ed.; Barnes, H.L., Ed.; John Wiley: New York, NY, USA, 1997; pp. 435-489.

54. Heinrich, C.A.; Driesner, T.; Stefansson, A.; Seward, T.M. Magmatic vapor contraction and the transport of gold from the porphyry environment to epithermal ore deposits. Geology 2004, 32, 761-764. [CrossRef]

55. Williams-Jones, A.E.; Heinrich, C.A. Vapor transport of metals and the formation of magmatic-hydrothermal ore deposits. Econ. Geol. 2005, 100, 1287-1312. [CrossRef]

56. Saunders, J.A.; Brueseke, M.E. Volatility of Se and Te during subduction-related "distillation" and the geochemistry of epithermal ores of western USA. Econ. Geol. 2012, 107, 165-172. [CrossRef]

(C) 2017 by the authors. Licensee MDPI, Basel, Switzerland. This article is an open access article distributed under the terms and conditions of the Creative Commons Attribution (CC BY) license (http:/ / creativecommons.org/licenses/by/4.0/). 